\title{
Evaluation of Teacher Professional Development Program-A Developmental Evaluation Approach
}

\author{
Su-ching Lin \\ Graduate Institute of Education, National Changhua University of Education, Taiwan \\ 1, Jin De Road, Paisha Village, Changhua City, Changhua County 500, Taiwan
}

Tel: 886-919-089047 E-mail: sclin@ cc.ncue.edu.tw

Received: May 12, 2020

Accepted: Oct. 7, 2020 Published: November 1, 2020

doi:10.5296/jse.v10i4.17932ＵRL: https://doi.org/10.5296/jse.v10i4.17932

\begin{abstract}
The professional development of teachers is the main mechanism for improving classroom teaching and improving students' learning outcomes. To have secondary school teachers improve their teaching by using the new teaching approach of project-based learning, this study engaged teachers to participate in Teachers' Project-Based Learning Program (T-PjBLP) to learn new knowledge, pedagogy, and skills. During the program implementation, the study applied a developmental evaluation (DE) approach to evaluate teachers' professional development and to assist them to develop an initiative program for students. In the DE approach, the role of the researcher was as a team member, shaped the course of development to help participants learn, and tracked the professional development process and results through a digital technology platform. The participants in this study consisted of 7 science teachers coming from two secondary schools. The major findings indicated that more than $95 \%$ of participants agreed that digital technology was a wonderful platform to provide them with an opportunity to share ideas, feedback, and experiences about what they learned from the program. Also, most of them provided positive feedback about their learning. To conclude, the program effectively changed teachers teaching beliefs from the teacher-centered approach to the learner-centered approach and used what they learned from the program to develop an initiative program for students. However, some limitations encountered in applying the DE approach to evaluate the program also were discussed in this study.
\end{abstract}

Keywords: Developmental evaluation, Project-based learning, Program evaluation, Teacher professional development program 


\section{Introduction}

Technology is the driving force for the progress of human civilization and the improvement of life. However, with the rapid development of technology, many changes have been brought about in people's lives: the disappearance of traditional enterprises, the increasing number of emerging jobs, the sharp increase in the gap between rich and poor, ethnic conflicts, disasters caused by extreme weather, the impact of globalization and anti-globalization. In the face of the treacherous environment, what competences school education should provide with students to adapt to the future environment, which constantly triggers discussion widely. Many countries around the world have proposed the framework of key capabilities in the $21 \mathrm{st}$ century. For example, the Partnership for the 21st Century Skills in 2002 proposed core competencies for the 21 st century that consisted of learning and innovative skills, core disciplines and issues, information and technology skills, and life and career skills (Harper, 2014; Kolk, 2018). The European Commission also proposed critical capacities for the $21 \mathrm{st}$ century, such as communication, digital literacy, learning how to learn, and cultural awareness (European Commission, 2006). In response to future development, Taiwan has implemented the reform of 12-year basic national education emphasizing developing people-oriented lifelong learners. Its core literacy is divided into three main areas: self-action, communication and interaction, social interaction. Reviewing the core competencies of the 21 st century mentioned by the c countries of the world, they all emphasize $4 \mathrm{C}$ abilities consisting of critical thinking, creativity, communication, and cooperation. However, the traditional teaching approach cannot be able to meet the needs of future education (Kolk, 2018).

Many studies pointed out that the effective approach for developing students' basic skills of the 21 st century must be task-oriented, interdisciplinary, collaborative, individualized, technological innovation, as well as on-campus and off-campus learning programs (Cook and Weaving, 2013; Harper, 2014). In other words, to effectively teach students with the basic skills of the 21 st century, teachers must create a learning environment in which students pursue knowledge through inquiry, as well as work collaboratively to research and apply their knowledge to resolve the real problem (Bell, 2010). Although appropriate approaches for teaching basic skills of the 21st century still have been debated, Ravitz et al. (2012) pointed out that project-based learning $(\mathrm{PjBL})$ has been proven by many studies to be the most common and effective teaching approach. One reason for this is that $\mathrm{PjBL}$ is typically interdisciplinary, meaning it can be adapted to multiple disciplines, core competencies, and horizontal skills at the same time and provides students with the opportunity to acquire in-depth content knowledge that is consistent with 21st-century skills (Harper, 2014).

Teachers' professional development is the main mechanism for improving classroom teaching and students' learning outcomes (Ball \& Cohen, 1999; Cohen \& Hill, 2000). The connection between teacher professional development and student achievement comes from the following steps. First, teachers improve their knowledge, skills, and motivation through professional development. Second, teachers apply the knowledge and skills acquired by professional development to the teaching in the classroom. Finally, teachers improve teaching and improve students' learning achievement through classroom practice (Yoon, Duncan, Lee, 
and Shapley, 2008). Therefore, a teacher professional development program is one of the key factors to improve teaching. Supovitz and Turner (2000) suggested that a high-quality program of professional development had to immerse participants in inquiry, questioning, experimentation, and model inquiry forms of teaching. That is, a high-quality program for teacher professional development must involve teachers in the curriculum, teaching, assessment, observation, and reflection so that professional development and classroom teaching have a close link (Borko, Jacobs, \& Koellner, 2010; Guo \& Yang, 2012). To have middle school teachers in Taiwan improve their teaching by using the new teaching approach of project-based learning, this study engaged teachers to participate in Teachers' Project-Based Learning Program (T-PjBLP) in which immerse participants in inquiry, questioning, experimentation, and model inquiry forms of teaching to learning new knowledge, pedagogy, and skills of PjBL.

Program evaluation is the systematic collection of information about the program as a basis for decision-making, and then take action to improve the quality of the program (Rossi, Lipsey, \& Freeman, 2004). There are many models for program evaluation, each with its characteristics, advantages, and limitations. Developmental evaluation (DE) is presented by a well-known American evaluator, Michael Quinn Patton. This model is an emerging evaluation approach in response to the rapidly changing social environment, complex social reforms, the needs of the program development process. DE approach has the following characteristics: (a) focus on the adaptive learning of the program developer, rather than the performance accountability assessment of the program itself; (b) the purpose of the evaluation is to provide more real-time feedback from program developers, to record the dynamics of the program development system, to show the track of the program development, and to stimulate the reform strategy and ideas; (c) the evaluator is also a number of the initiative program team, whose role is not only to collect and analyze data but also to be actively involved in the development of the shaping program, providing information that contributes to decision-making and promotes team learners; (d) as the development of the program or the objectives of the continuous adjustment, the continuous development of new measurement methods and monitoring mechanisms, is a very flexible and flexible evaluation model (Patton, 2011). In other words, DE replaces the way the traditional linear line and the fixed evaluation mode of predictive logic work, combining the rigor of evaluation with the flexibility, imagination, and real-time feedback to meet the needs of program initiative development whose processes are full of high uncertainty, innovation, and complexity and create new insights to understand, to learn and to improve the initiative program (Gamble, 2008; Patton, 2008).

Due to its characteristics, in recent years, the DE has been recognized as a model for the evaluation needed for social innovation and initiative programs and is used widely in the evaluation of initiative programs (McDonald, 2016). The purpose of the T-PjBLP in this study was to enhance teachers' professional knowledge and skills of PjBL and facilitated them to apply what they learned from the program to develop an initiative program of PjBLP for their students. Therefore, this study used the DE to assist teachers' professional growth and help them to transform theory into practice. The research questions in this study were as 
follows:1) What was the participant's satisfaction with the design and implementation of the program? 2) What extent was the change in teachers' beliefs? 3) How did teachers apply what they learned from the program to develop the student a PjBL program? 4) What were the limitations or issues of applying the DE evaluation model in this study?

\section{Methodology}

\subsection{Participants}

The participants in this study consisted of seven secondary school science and technology teachers from two schools located in central Taiwan including 2 males and 5 females. These seven teachers were invited to attend the training program because they wish to innovate their teaching strategies and improve the practice of class teaching.

\subsection{Program description}

The theory resources of the T-PjBLP can trace back to experiential learning theory and social constructivism. Experiential learning theory advocated by David Kolb, which integrated John Dewey's learning by doing and Kurt Lewin and Jean Piaget's cognitive development theory and other scholars' theory. Later, it was widely used and became one of the most important theoretical structures of experience teaching. The learning process of experiential learning theory consists of four stages. First, "concrete experience" which emphasizes learning with a personal feeling and interesting. Concrete experience can improve students' willingness to learn. Second, "reflective observation" emphasizes looking at things from different perspectives to find the true meaning of things. Third, "abstract conceptualization" which emphasizes that experience must go through the structured process of systematic ideas before being constructed into reliable knowledge. Fourth, "active experiment" which stresses practical learning, the patience to get things done, and taking action to influence the people around you.

Social constructivism holds that knowledge construction is both a social and a cognitive process. Knowledge and meaning are constructed through the processes of frequent dialogue, active agreement, cooperative cooperation in the social context. That is, through interaction with the environment, the individual can create meaning (Brush \& Saye, 2000; Vygotsky, 1978). Therefore, social constructivism advocates a learner as the center, while an instructor plays the role of facilitator, guiding the learner to learn based on the progress and process of learning. Through project-based learning, learners are assigned tasks to achieve specific teaching objectives through discussion, inquiry, communication, creativity, and problem solving (Han \& Bhattacharya, 2001). That is, create your own understanding and knowledge of the world through experiences and reflection on those experiences. When students encounter new things, they must connect new knowledge with known knowledge, combine it with previous ideas and experiences, and create their own understanding and knowledge of the world.

The component of the program consisted of four parts: concept construction, experiential learning, and students' $\mathrm{PjBL}$ program development. "Concept construction" included understanding the connotation of the core competency of the 21 st century and its importance 
to the future development of students; The correlation between PjBL teaching approach and the core ability of the 21st century; PjBL's characteristics, curriculum design, teaching process, learning assessment, advantages, and challenges. "Experiential learning" on which participants actually engaged in $\mathrm{PjBL}$ exploration of the processes by explorative teaching, assessment, observation, and reflection. In the "program development" participants firstly deconstructing and constructing teaching materials in the field of nature and science and technology. Secondly, investigate the problems and resources of the community. Thirdly, design PjBL units. Then take explorative teaching.

The program activities mainly consisted of self-directed learning, professional dialogue, lectures, experience sharing, sample studies, development programs, teaching video watch, tentative experimental teaching, etc., which was implemented through the cross-school professional learning community modes. Participants attended a 78-hour workshop related to the teaching approach of project-based learning to enhance their professional knowledge, skill, teaching beliefs, and program development. Individual workshop was three hours at a time and take turns in the audio-visual classrooms of the two schools. Participants had to commit to a full year school year of engaging in workshops. Specific topics of the program were listed in Table 1.

Table 1. topics of the program

\begin{tabular}{|l|l|c|}
\hline component & \multicolumn{1}{|c|}{ topic } & hour \\
\hline concept construction & The core competency and education of the $21^{\text {st }}$ century & 3 \\
\cline { 2 - 3 } & The role and responsibilities of teachers in the $21^{\text {st }}$ century & 3 \\
\cline { 2 - 3 } & PjBL associate with core competency in the $21^{\text {st }}$ century & 3 \\
\cline { 2 - 3 } & Key concepts of PjBL & $3 * 2=6$ \\
\cline { 2 - 3 } & Elements of PjBL curriculum design & $3 * 2=6$ \\
\cline { 2 - 3 } & Implementation and impact factors of PjBL & $3 * 2=6$ \\
\cline { 2 - 3 } & case analysis of PjBL & $3 * 2=6$ \\
\hline Experiential learning & Experience the process of PjBL & $3 * 2=6$ \\
\cline { 2 - 3 } & Present the results of the project & $3 * 2=6$ \\
\hline & Tentative PjBL unit design & $3 * 2=6$ \\
\cline { 2 - 3 } & explorative teaching of PjBL & $3 * 5=15$ \\
\cline { 2 - 3 } & Develop S-PjBLP & 3 \\
\hline
\end{tabular}

\subsection{Program evaluation}

The researcher used the perspective of the developmental evaluation (ED) approach to evaluate T-PjBLP. First, the researcher built the network platform called "T-PjBLPed" before the program implementation. Then, guide participants learned how to use the platform to upload materials, download materials, and share ideas. PjBLPed platform included four parts: Learning Garden, Teacher e-portfolios, Feedback and Discussion, and Issues and Responses. During program implementation, the researcher tracked the participants' adaptive learning and more real-time feedback, recorded the dynamics of the students' program development system, and stimulated the reform strategy and ideas to participants. The role of the researcher was not only to collect and analyze data but also to be actively involved in the 
development of the shaping program, providing information that contributes to decision-making and promotes team learners.

\subsection{Data collection}

Data collection consisted of qualitative and quantitative data described below:

\subsubsection{Program Design Checklist}

The author developed program design checklist to understand the relevance and appropriateness of the T-PjBLP design, asked participants filled out the checklist on the T-PjBLPed website. The checklist consisted of open and closed questions. The participants responded to each closed question on a four-point Likert scale in the checklist, ranging from 1 for "strongly unsuitable" to 4 for "strongly suitable." For example, a closed question was "the length of the activity is suitable" ; An open question was "do you any suggestion for program topics?"

\subsubsection{Activity Feedback Survey}

The author developed activity feedback survey to understand the participants' reactions to the program implementation, the researcher asked participants to fill out the survey for each workshop to provide feedback on the T-PjBLPed website after the end of workshops. The survey included open and closed questions. The participants responded to each closed question on a four-point Likert scale in the survey, ranging from 1 for "strongly unsatisfied" to 5 for "strongly satisfied." For examples, a closed question was "the content of workshop is benefit to improve your teaching"; an open question was "do you have any suggestion to this workshop?"

\subsubsection{E-portfolio document}

During the program implementation, ask each participant to build their own e-portfolio of professional growth in the T-PjBLPed website and shared their program experience, expertise skills, and attitudes learned from the program with other participants.

\subsubsection{Teacher Belief Scale}

This study developed the Teacher Belief Scale (TBS) based on Zhu and Ye (2001) to measure teachers' teaching belief change to assess the impact of the program. TBS consisted of 3 dimension questions including opinions of curriculum and instruction design (9 items), teaching and assessment (16 items), and student learning (9 items). Each dimension included two-approach questions: teacher-centered (TC) and learner-centered (LC). Teachers responded to the items on a six-point Likert scale, ranging from 1 for "strongly disagree" to 6 for "strongly agree". The factor analysis showed that explaining the amount of variation for subscales from $39.33 \%$ to $44.81 \%$, indicating the good validity of the items within this scale. The Cronbach's $\alpha$ for the three subscales ranged from .57 to .80, indicating good internal consistencies of the items within each subscale.

2.4.5 Teacher knowledge Test 
Teacher Knowledge Test (TKT) developed by the researcher was administered to measure teachers' knowledge change to know what participants learned from the T-PjBLP via comparison of the means of pre-test score and the post-test score. Therefore, participants had to finish the TKT pre-test before the program implementation and finish post-test at the end of program implementation. TKT included 20 single-choice questions related to $\mathrm{PjBL}$ referring to theory resources ( 5 items), curriculum design ( 5 items), instruction ( 5 items), and assessment (5item). 0 points for a wrong answer, 5 points for the right answer. The total is 100 points.

\subsubsection{Unit design document}

After experiencing the process of the $\mathrm{PjBL}$ approach, participants divided into two groups tried to transform PjBL theory into teaching practice by jointly designing the PjBL unit for eight-graders and provide a reflection on curriculum development. The study tried to analyze how participants apply a "learner-centered" approach to develop appropriate students' PjBLP units that will be implemented in the next academic year. The unit design consisted of four parts: community exploration, core knowledge, project inquiry, and outcome presentation. "Community exploration" referred to understand the problems, resources, industries, and professionals of the community linking with core concepts of the subject, real-world issues or issues, and community professionals. "Core knowledge" covered the core concept of science, the ability of inquiry, the attitude and essence of science, information technology, life science, and technology. "Project inquiry" in which students drive their own learning through inquiry, as well as work collaboratively to research and create projects that reflect their knowledge. "Outcome presentation" should include how to exhibit the outcome of the promotion of students' critical thinking, interpersonal communication, creative thinking, collaborative cooperation, and the application of science and technology.

\section{Results}

\subsection{Program design evaluation}

The participants provided opinions based on the questions of the checklist. The result shown in Table 2 indicated that the program design was appropriate to participants.

Table 2. Summary of the responses of program design $(n=7)$

\begin{tabular}{|l|l|l|l|l|}
\hline Check List & SU \% & U \% & S \% & SS \% \\
\hline 1. topics are suitable. & 0 & 0 & 85.71 & 15.29 \\
\hline 2. the frequencies of the activities are suitable. & 0 & 0 & 71.42 & 29.58 \\
\hline 3. the length of the activity is suitable. & 0 & 0 & 85.71 & 15.29 \\
\hline 4. there is conformity between the topics and activities. & 0 & 0 & 71.42 & 29.58 \\
\hline 5. there is a relevance between expected results and topics. & 0 & 0 & 100.0 & 0 \\
\hline $\begin{array}{l}\text { 6. the relevance between expected results and activities is } \\
\text { adequate. }\end{array}$ & 0 & 0 & 85.71 & 15.29 \\
\hline 7. overall design is sound. & 0 & 0 & 57.14 & 42.86 \\
\hline
\end{tabular}




\section{NI Macrothink}

recommend: Both the topics and activities of the program were well designed, especially building the T-PjBLPed website which will be a wonderful platform to provide participants with an opportunity to share ideas, feedback, and experiences about what they learned from the program.

Notes: $\mathrm{SU}=$ strongly unsuitable, $\mathrm{U}=$ unsuitable, $\mathrm{S}=$ suitable, $\mathrm{SS}=$ strongly suitable

\subsection{Program implementation evaluation}

Participants were asked to fill out the activity survey which consisted of four dimension questions including topic, activity, content, and professional development after each workshop. The result of the program activity satisfaction analysis was shown in Table 3.

Table 3. Summary of the activity feedback of program implementation $(n=7)$

\begin{tabular}{|l|l|l|l|l|l|}
\hline dimension & $\mathrm{SU}(\%)$ & $\mathrm{U}(\%)$ & $\mathrm{N}(\%)$ & $\mathrm{S}(\%)$ & $\mathrm{SS}(\%)$ \\
\hline topic & 0 & 0 & 0 & 0 & 100.0 \\
\hline activity & 0 & 0 & 0 & 85.71 & 15.29 \\
\hline content & 0 & 0 & 0 & 71.42 & 29.58 \\
\hline Professional development & 0 & 0 & 0 & 57.14 & 43.86 \\
\hline overall & & & & 53.55 & 46.45 \\
\hline
\end{tabular}

Notes: $\mathrm{SU}=$ Strongly Unsatisfied, $\mathrm{U}=$ Unsatisfied, $\mathrm{N}=$ Normal, $\mathrm{S}=$ Satisfied, $\mathrm{SS}=$ Strongly Satisfied

Except for closed-ended questions, the activity feedback survey also included open-ended questions related to what the participants learned the most or what impressed them the most in the activity. Most of the participants provided very positive feedback on program implementation. For examples:

Overall, the schedule of the workshop is appropriate and convenient for me to participate in. And the content of the workshop is impressive and can enhance self-expertise. (E-portfolio A)

The most important thing that I learned from the workshop is that a teacher should not be afraid of change and should continuously reflect on his/her own teaching belief and practices. (E-portfolio B)

Overall, I am very satisfied with the implementation of the program, the topic of each workshop is very interesting. Besides, I am very impressed by the instructor's PjBL teaching strategies which bring me professional growth and improve my teaching in the class. (E-portfolio C)

The contents of the workshops are not too difficult to understand and do not deviate from my actual needs. What I learned from the workshops will benefit my teaching (E-portfolio D)

The best thing I learned from the workshops is how to effectively constructed knowledge through collaborative learning. This teaching experience greatly benefits me and provides me 
a lot of thoughts and patterns in teaching design. (E-portfolio

E)

The most impressive part of the workshop is that the instructor designed wonderful questions, which were able to guide students in engaging themselves in discussions. It helps me to think of how to improve my curriculum design. (E-portfolio F)

In the unit design workshop, the most impressive thing is the grouping process. It is important to collaborative learning activities because it is a key factor in bringing peers' dialogues. (E-portfolio G)

\subsection{Program outcome evaluation}

\subsubsection{Teacher belief change}

Teacher Belief Scale (TBS) was a pre-test and post-test tool to measure teachers' teaching belief change to assess the impact of the program. TBS consisted of 3 dimension questions: Curriculum design, teaching and assessment, and student learning. Each dimension included both teacher-centered (TC) and learner-centered (LC) approach questions. Table 4 showed the pre-test means of the TC approach were lower than the post-test means in TBS, meanwhile, the pre-test means of the LC approach were higher than the post-test means in TBS. This result indicated teachers' belief change from the teacher-centered approach to the learner-centered approach after they attended a 78-hour workshop. In other words, T-PjBLP causes a change in teachers' teaching beliefs.

Table 4. The mean and standard deviation of pre-test and post-test in TBS(N=7)

\begin{tabular}{|l|l|l|l|l|l|l|}
\hline & & & Pre-test & & Post-test & \\
\hline dimension & approach & Items & M & SD & M & SD \\
\hline CD & LC & 5 & 4.54 & 1.01 & 2.57 & 0.92 \\
\hline & TC & 4 & 2.25 & 0.89 & 4.46 & 1.00 \\
\hline TA & LC & 8 & 1.96 & 0.76 & 4.64 & 0.92 \\
\hline & TC & 8 & 4.86 & 0.82 & 2.29 & 0.82 \\
\hline SL & LC & 6 & 2.00 & 0.70 & 4.95 & 0.82 \\
\hline & TC & 3 & 5.00 & 0.89 & 2.14 & 0.65 \\
\hline
\end{tabular}

\subsubsection{Teachers' knowledge change}

Teacher Knowledge Test (TKT) was administered to measure teachers' knowledge change to know what participants learned from the T-PjBLP. Table 5 and figure 1 showed the correct percentages of the post-test were higher than the those of pre-test in TKT. The result indicated teachers' knowledge change after they attended a 78-hour workshop. In other words, T-PjBLP enhanced teachers' understanding of the project-based learning approach.

Table 5. correct percentages of pre-test and post-test of TKT $(\mathrm{N}=7)$

\begin{tabular}{|l|l|l|l|l|}
\hline teacher & Theory resources & curriculum design & teaching activity & learning assessment \\
\hline
\end{tabular}




\begin{tabular}{|l|l|l|l|l|l|l|l|l|}
\hline code & Pre-t & Post-t & Pre-t & Post-t & Pre-t & Post-t & Pre-t & Post-t \\
\hline A & 20 & 80 & 20 & 80 & 20 & 80 & 0 & 100 \\
\hline B & 40 & 100 & 40 & 80 & 40 & 80 & 0 & 100 \\
\hline C & 20 & 80 & 40 & 100 & 20 & 80 & 20 & 80 \\
\hline D & 40 & 100 & 20 & 100 & 20 & 100 & 20 & 80 \\
\hline E & 20 & 80 & 0 & 80 & 20 & 80 & 20 & 100 \\
\hline F & 20 & 60 & 0 & 80 & 40 & 100 & 40 & 80 \\
\hline G & 40 & 80 & 20 & 60 & 20 & 80 & 20 & 80 \\
\hline Overall & 31.42 & 82.85 & 20.00 & 82.85 & 25.71 & 85.71 & 17.14 & 88.57 \\
\hline
\end{tabular}

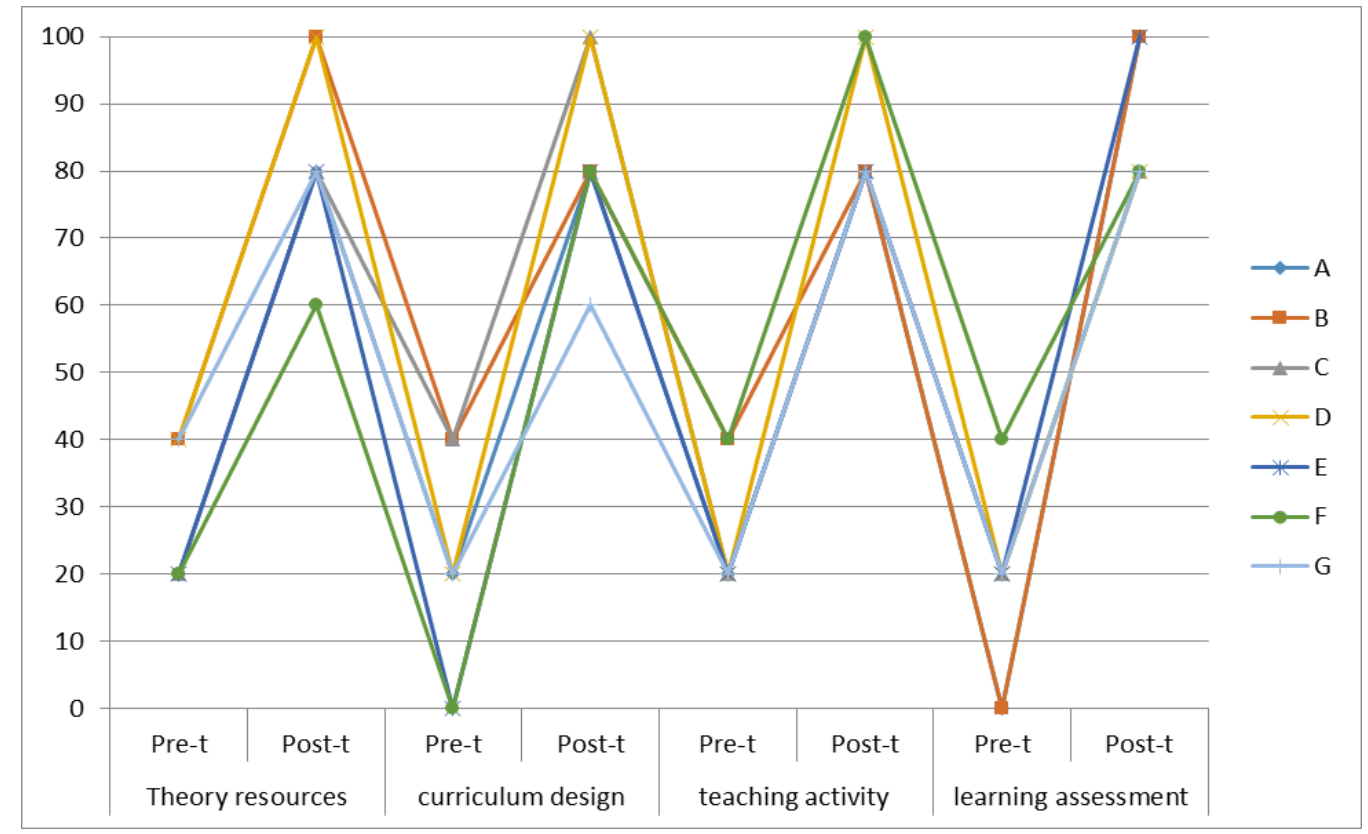

Fig.1 correct percentages of pre-test and post-test of TKT

Participants also shared what concepts they learned from the program on the web platform. Extracted as follows:

$\mathrm{PjBL}$ is an innovative approach to benefit students with becoming proficient communicators and advanced problem solvers (E-portfolio A).

PjBL is a student-centered, teacher-facilitated approach to learning. Students develop a question and are guided through research under the teacher's supervision. Also, PjBL can promote interpersonal interaction of children and learn skills of communication, negotiation, and collaboration (E-portfolio B). 
$\mathrm{PjBL}$ is a teaching approach through a project to teach students core concepts of courses. The topic of the project is a real-world problem that drives students to inquiry and allows them to apply their acquired knowledge (E-portfolio C).

The assessment of PjBL includes self-evaluation and reflection. Students self-evaluate their own projects, efforts, motivations, interests, and productivity levels and also become critical friends by giving constructive feedback to each other (E-portfolio D).

The $\mathrm{PjBL}$ is an innovative teaching approach. However, I guess when teachers choose to use $\mathrm{PjBL}$ in their classroom, they might face certain challenges, such as the problem of classroom discipline (E-portfolio E).

PjBL engages learners in complex activities and focuses on the creation of a product or performance. Students choose and organize their activities, conduct research, and synthesize information, which will cultivate students' various capabilities (E-portfolio F).

I believe PjBL is a wonderful teaching approach but I think a teacher wants to apply the PjBL approach successfully, he/she needs to be skilled in taking a student-centered approach, need to have the motivation and the abilities to adopt a new instructional strategy, and need to be confident in managing the PjBL activities. (E-portfolio G)

\subsubsection{Teachers' skill change}

Participants were asked to apply a "learner-centered" approach to develop PjBLP for their students at the end of the program. From the unit document they designed, one can found that they were able to design an appropriate unit consisting of community exploration, knowledge of natural science and technology, and project investigation. The main teaching process of the unit includes (1) apply the events to stimulate students' interest to explore the topic. (2) Assign tasks so that students are proficient in monitoring their learning progress and using their time effectively. (3) To provide resources or advice for each group. (4) To assist and guide students to reduce the gap of knowledge and skills. (5) Students work together through goal setting to accomplish the tasks they are responsible for and complete the final works. (6) To guide students to actively participate in investigating and solving problems. (7) Provide students with the opportunity to reflect on their works and provide feedback and revisions. (8) Each group presents the results publicly, which promotes the quality that students are more concerned about and makes learning more meaning

\section{Conclusion and Discussion}

This study applied a developmental evaluation approach to evaluate a teacher professional development program (T-PjBLP). The purpose of the T-PjBLP was to transform teachers' teaching beliefs from teacher-centered to student-centered pedagogy and to enhance their PjBL curriculum design and practical ability for the effective development of students' basic skills in the $21^{\text {st }}$ century.

The participants in this study consisted of 7 science teachers coming from two secondary 
schools. During the program implementation, this study tracked teachers' professional development processes and results through digital technology platforms to collect data and actively to ask questions, discuss, provided information, and real-time feedback, and adjusted the program. The study used the program design checklist, activity responses of the workshop, teachers' e-portfolio, teachers' belief survey, and unit design documents to collect data.

The major findings indicated that more than $95 \%$ of participants agreed that digital technology was a wonderful platform to provide them with an opportunity to share ideas, feedback, and experiences about what they learned from the program. Also, most of them provided positive feedback about their learning. moreover, the program effectively changed teachers teaching beliefs from the teacher-centered approach to the learner-centered approach and used what they learned from the program to develop an initiative program for students.

Overall, the design, implementation, and the expected outcome of the T-PjBLP were appropriate. The program enhanced teachers' knowledge of the $\mathrm{PjBL}$ and change their teaching beliefs from a teacher-centered approach to a student-centered approach. These results supported that teacher professional development program improves teachers' performance and draws more their attention to students' needs. The study confirmed that a cross-school professional learning community used in this study was an effective approach for professional development through the ways of professional dialogue, curriculum development, peer supervision, peer coaching, and action research. Based on the result of this study, the researcher believes that throughout the T-PjBLP intervention, teachers will fulfill their pedagogy that learning should be a sustainable process of "constantly weaving the relationship and the meanings" by having dialogues with learning materials, with peers, and with oneself in the experimental teaching in the following year.

However, some limitations encountered in applying the DE approach to evaluate the program in this study. According to Guijt, Kusters, Lont, and Visser, (2012), DE is at the end of the spectrum of 'process use' - the questioning and reflecting on an evolving process is what is valuable. The impact on our program came not so much from the findings but from going through the thinking process that the evaluation required. DE approach to intentionally build capacity is necessary if we want organizations to learn and embed evaluative inquiry (Preskill \& Boyle, 2008). Thus, it will be necessary to build a body of knowledge around DE with particular emphasis on sharing experiences from both the evaluator and stakeholder perspectives. However, missing in the literature were further examples of how the DE approach supports capacity building in practice in this study.

Moreover, as Poth, Pinto, and Howery's (2012) research indicated, the new approach caused tension during the data collection phase in the first year. Developing instruments to measure outcomes was impossible given that the project was still being developed. Within DE, the larger questions are asked about how short-term results relate to outcomes and changes on the system level (Guijt, Kusters, Lont, \& Visser, 2012). The current study also encountered this challenge.

Finally, Patton (2011) indicated DE is not prescriptive in the manner in which it is approached and applied. The design and methods depend on the nature of the situation and 
the key questions that need to be answered to progress its development. However, some case studies note the challenges of data collection in a fast-moving development, where issues emerge quickly and the desire for real-time feedback makes collecting reliable data difficult (McDonald, 2016). This study also faced a similar problem.

\section{Acknowledgments}

The research is financed by the Ministry of Science and Technology, Taiwan. No. MOST 108-2410-H-018-016-MY2

\section{References}

Ball, D., \& Cohen, D. (1999). Developing practice, developing practitioners: Toward a practice-based theory of professional education. In L. Darling-Hammond \& G. Sykes (Eds.), Teaching as the learning profession (pp. 3-32). San Francisco, CA: Jossey-Bass.

Ball, DL, Thames, MH, Phelps, GC (2008). Content knowledge for teaching: What makes it special? Journal of Teacher Education, 59(5), 389-407. https://doi.org/10.1177/0022487108324554

Bell, J. (2010). Doing your research project: A guide for first-time researchers in education, health and social science. Maidenhead: McGraw-Hill Open University Press.

Borko, H., Jacobs, J., \& Koellner, K. (2010). Contemporary Approaches to Teacher Professional Development. In P. Peterson, E. Baker, \& B. McGaw (Eds.), International Encyclopedia of Education (pp. 548-556). Oxford: Elsevier. https://doi.org/10.1016/B978-0-08-044894-7.00654-0

Cohen, D. K., \& Hill, H. (2000). Instructional policy and classroom performance: The mathematics reform in California. The Teachers College Record, 102, 294-343. https://doi.org/10.1111/0161-4681.00057

Cook, R. and Weaving, H. (2013). Key Competence Development in School Education in Europe: KeyCoNet's Review of the Literature: a Summary. Brussels: European Schoolnet.

Coryn, C. L. S., Noakes, L. A., Westine, C. D., \& Schro“ ter, D. C. (2011). A systematic review of theory-driven evaluation practice from 1990 to 2009. American Journal of Evaluation, 32(2), 199-226. https://doi.org/10.1177/1098214010389321

Donaldson, S. I. (2007). Program theory-driven evaluation science. New York, NY: Lawrence Erlbaum. https://doi.org/10.4324/9780203809730

Gamble, J. A. (2008). A developmental evaluation primer. Montreal: JW McConnell Family Foundation.

Grossman, P., \& McDonald, M. (2008). Back to the future: Directions for research in teaching and teacher education. American Educational Research Journal, 45(1), 184-205. https://doi.org/10.3102/0002831207312906

Guijt, I., Kusters, C.S.L., Lont, H., \& Visser, I. (2012). Developmental Evaluation: Applying complexity concepts to enhance innovation and use: Report from an Expert Seminar with Dr. Michael Quinn Patton. Centre for Development Innovation, Wageningen University \& Research centre. Retrieved from http://edepot.wur.nl/216077

Guo, S. \& Yang, Y. (2012). Project-based learning: an effective approach to link teacher 
professional development and students learning. Journal of Educational Technology Development and Exchange, 5(2), 41-56. https://doi.org/10.18785/jetde.0502.04

McDonald, H. (2016). Developmental evaluation: A tool to support innovation. https://doi.org/10.18296/em.0012

Patton, M. Q. (2008). Utilization-focused evaluation: The new century text (4th ed.). Thousand Oaks, CA: sage.

Patton, M. Q. (2011). Developmental evaluation: Applying complexity concepts to enhance innovation and use. New York, NY: The Guilford Press.

Poth, C. A., Pinto, D., \& Howery, K. (2012). Addressing the challenges encountered during a developmental evaluation: Implications for evaluation practice. The Canadian Journal of Program Evaluation, 26(1), 39-48.

Ravitz, J. (2008). Project Based Learning as a Catalyst in Reforming High Schools. Retrieved from https://eric.ed.gov/?id=ED540113

Ravitz, J., Hixson, N., English, M., \& Mergendoller, J. (2012). Using project based learning to teach 21st century skills: Findings from a statewide initiative. Paper presented at Annual Meetings of the American Educational Research Association. Vancouver, BC.

Rossi, P.H. \& Freeman, H. E. (1985). Evaluation: a systematic approach (3rd ed.). Beverly Hills, CA: Sage.

Supovitz, J. A., \& Turner, H. M. (2000). The effects of professional development on science teaching practices and classroom culture. Journal of Research in Science Teaching, 37(9), 963-980. https://doi.org/10.1002/1098-2736(200011)37:9<963::AID-TEA6>3.0.CO;2-0

Yoon, K. S., Duncan, T., Lee, S. W.-Y., Scarloss, B., \& Shapley, K. (2007). Reviewing the evidence on how teacher professional development affects student achievement (Issues \& Answers Report, REL 2007-No. 033). Washington, DC: U.S.

Zhu, W. -U., \& Ye, W. -Z. (2001). The compilation of the teacher's belief scale. Retrieved from http://www3.nccu.edu.tw/ ycyeh/instrument-english/2001\%20teacher\%20belief.pdf 